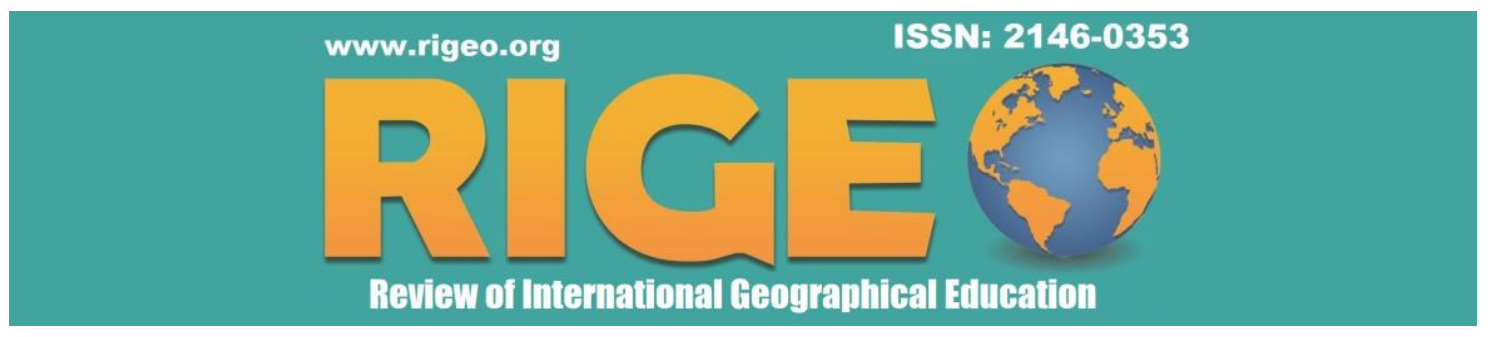

(C)IGEO, Volume 10, Issue 1 (Special Issue), 2020

Research Article

Copyright $\odot$ RIGEO 2020

To cite this article: Kuzey, M. (2020). Preservice Teachers' Metaphors about the Concept of Space Perception. Review of International Geographical Education (RIGEO), 10, (1), Special Issue, 140-158. Retrieved from http://www.rigeo.org/vol10no1/Number1Spring/RIGEO-V10-N1-7.pdf

DOI: 10.33403rigeo.641606

Submitted: November 01, 2019

Revised: December 17, 2019

Accepted: February 09, 2020

\title{
Preservice Teachers' Metaphors about the Concept of Space Perception*
}

\author{
Mehmet KUZEY ${ }^{1}$ \\ Bayburt University, Bayburt, TÜRKIYYE
}

\begin{abstract}
The aim of this study is to reveal the metaphors produced by the students of the Faculty of education regarding the concept of space perception. In accordance with this aim, the phenomenon design from qualitative research designs was used. The working group consists of 261 teachers who study in the Departments of Bayburt University Faculty of Education, Turkish, Social Sciences and primary education in the 2018-2019 academic year. "Perception of spatial" in order to determine the metaphors produced by the teacher candidates for the concept of "perception of spatial"... like/is similar to because... "the semi-structured form containing the statement was distributed and they were asked to convey their thoughts. The data obtained at the end of the study were analyzed in accordance with the content analysis. Participants produced a total of 109 valid metaphors for the concept of space perception, and these metaphors were grouped under 10 different categories. As a result of the study, it was determined that half of the teachers associated the concept of space perception directly with the words that contain the meaning of the concept of space.
\end{abstract}

\section{Keywords}

Spatial, Perception of Spatial, Metaphor, Perception of Spatial Metaphor, Teacher Candidates'

The world is a life that defines the existence of man and allows him to survive. The world is a place where human lives and then passes away (Çağbayır, 2009). People conduct humanities activities at this mansion site. As a result of these activities produced, marketed and transformed (Lagopoulos, 2009) conceptualized the place of

\footnotetext{
*A portion of this research was presented in 2. International Congress on Geographical Education (UCEK/ICGE-2019), 3-5 October 2019, Eskişehir-Turkey.

${ }^{1}$ Bayburt University, Faculty of Education, Department of Turkish and Social Studies Education, Bayburt, Turkey. E-mail: memetkuzey [at] bayburt.edu.tr. ORCID: 0000-0002-9866-8134.
} 
the mansion as a place (Radden, 2003). Place, which is the reason of people's existence; place, home, home; sky, placece (Turkish language institution [TDK], 2011) meaning an empty environment, infinity, the place where the facts are classified, mental and social relationship place (Lefebvre, 2016) is also defined as.

Human is an entity shaped by stimulating characteristics from place, social culture and his own experiences. It perceives, makes sense, and internalizes all these stimulating properties in the string of values. Ontological sense reflects the intellectual and operational world in which man interacts with place (Şahin, 2017). Man has also seen metaphors as a way of understanding and expressing his own thoughts, dreams, experiences (Gibbs, Lima and Francozo, 2004) and the real world (Burmakova and Marugina 2014; Bonde, 2005). Thus he has expressed similar or different aspects of reality in the human mind using metaphor (Turner, 1993; Burmakova and Marugina 2014).

Metaphors are generally defined as a mapping process between two different conceptual domains: The target Field (the concept to be defined by the metaphor) and the Source field (the concept that is drawn or used to construct the metaphorical structure) (Burmakova and Marugina 2014). This matching process is a function of making human concepts (Source field concept) more comprehensible with other concepts (Target Field concept) (Dos Santos, Gros, Abel, Loisel, Trichaud, and Paris 2000). It also makes sense of abstract concepts and further embodies them (Lakoff and Johnson, 2015; Slepian and Ambady, 2014).

Metaphors reflect the culture of the nation as an expression of beliefs and values, such as those in ontological terms that reflect human experiences (Ahn and Kwon, 2007) (Steen, 2010; Burmakova and Marugina, 2014). How the space that forms the basis for human existence is perceived by man and expressed metaphorically is seen as important for this research. Because just as human builds the reality he lives in through metaphors, metaphors also reveal what is in the human mind and make it even more visible (Lakoff and Johnson, 2015). Metaphors in this context are one of man's methods of receiving information, coding knowledge, and expressing themselves (Nelson and Simmons, 2009). This method simplifies, codes and sorts the complex world between man and space (Kitchin, 1994).

People metaphors in science, education, art, literature, religion, etc. they use it in fields (Steen, 2010). They are widely used in the field of education because metaphors attribute concepts, make them easier to understand, are frequently used in everyday life, and are an integral part of thought and reasoning (Lakoff and Johnson 2015). It is also a method that educators refer to in teaching certain concepts and subjects (Değirmenci, 2019a). Sir Arthur Eddington used metaphors for the first time in education. Since then, it has been used in all areas of education all over the world (Güneş, Tezcan, 2017).

Education is the process of creating changes in the individual's behavior through his / her own life and deliberately in the direction in which we are asked (Ertürk, 1997). Planning and programming the training process effectively is extremely important. A qualified and rich learning experience can only be gained through a well-regulated education process (Bulut, 2019). Students form perceptions of place and perceptions 
acquired through sensory organs on the properties of a particular object such as direction, size, shape, distance (Köktürk, 2010). These perceptions of place are the reflection of common symbols of place (Salan and Gürani, 2019). In this context, it is seen that the ability to perceive place is included in the 2018 life sciences, social sciences and Turkish course curriculum.

Life science course curriculum" acquires the ability to perceive time and place "special purpose and" place perception and nature protection" skills are included. In the program (LS.1.1.2., LS.1.1.4., LS.1.1.7., LS.1.2.3., LS.1.5.1., LS.1.5.2., LS.1.6.4., LS.1.6.6., LS.2.1.5., LS.2.2.3., LS.2.5.1, LS.2.6.3., LS.2.6.5., LS.2.6.6., LS.2.6.8., LS.3.1.5., LS.3.2.3., LS.3.6.3., LS.3.6.4 and LS.3.6.5.) (MEB, 2018a) attainments have been associated with space perception skills. In the theme of "time and place" under the title of Turkish lesson explanations on themes "our environment, our home, past now future, travelers, our room, our school, cities, our classroom, countries etc."and in the theme of "our national culture", it includes suggestions on topics such as "places and historical sites" (MEB, 2018b). The general objectives of the social sciences course curriculum are "(5) to explain the interaction between human and environment by recognizing the general geographical features of the world and to improve the perception of place". In the program, basic skills such as "(1) sensing place, (2) map literacy and (3) location analysis" were associated with the ability to perceive space. Social sciences lesson to be considered in the implementation of the curriculum section " (7) social sciences education should be given importance to benefit from non-school environments. These studies may be aimed at marketplaces, government offices, archaeological excavation sites, workshops, museums and historical sites from the close vicinity of the school". Social sciences in the field of" people, places and environments "learning has been stated to" aim to attainments students the spatial basic knowledge, skills and values necessary for human life". Social sciencees course (SS.4.3.1., SS.4.3.2., SS.4.3.2., SS.4.3.5., SS.5.3.1., SS.5.3.2., SS.5.3.3, SB.5.3.4., SS.5.3.5., SS.6.3.1., SS.6.3.2., SS.6.3.3. and SS.6.3.4.) (MEB, 2018c) attainments have been associated with the ability to perceive place. As well as giving the ability to perceive place in these teaching programs, it is equally important to present the ideas of the teachers about their knowledge, skills and values about the ability to perceive space.

Metaphors in education for the use of the literature (Hopkins (2002); Cerit, 2008; Saban, 2008; Aydın and Pehlivan, 2010; Aydın, 2011; Geçit and Gençer, 2011; Akbaş and Gençtürk, 2013; Bektaş and Karadağ, 2013; Bektaş, Okur and Karadağ, 2014; Kelleci, 2014; Caballero, 2014; Lakoff and Johnson, 2015; Durmuş and Baş, 2016; Karacabey and Bozkuş, 2016; and Karapınar and Arıbaş, 2017; Erdilmen-Ocak, Çiydem and Mindivanli-Akdogan, 2017; Duran and Aladağ, 2018; Beyoğlu and Ergin, 2018; Erdi-Es, 2018 Yazıcı; Ulu-Kalın, 2018; Değirmenci and Eskici 2019 It appears that researchers such as) have done research on concept metaphors. There appears to be a limited number of studies on the perception of place. Metaphors are used as a learning and teaching method in education. Determining how the teacher candidates develop a perception while learning the concept of place perception and what kind of metaphors they learn is among the reasons for the research. The results of this research can give clues about how the students will learn the concept of perception of place and how they 
will teach it tomorrow. In this context, teacher training is a multifaceted issue and is the most important element of the education system (Kavcar, 2002). It is thought that this research will contribute both to literature and lead to better equipped training of teacher candidates. In this way, candidates who learn about the method of metaphor in their education will have the chance to use the method of metaphor correctly when educating their students. Thus, a healthy communication between man and place will be realized. Turkish and Turkish, Social Sciences and Primary Education Departments of the Faculty of Education, Social Sciences and Primary Education Departments of the aim of this study is to determine the metaphorical perceptions of candidates for the concept of space perception. Within the framework of this objective, answers to the following problems were sought.

1. What metaphors do teachers use to explain their perceptions of the concept of spatial perception?

2. What categories are the metaphors that teachers have about the concept of perception of spatial according to their common characteristics?

\section{Methodology}

The research used in the design under this heading includes information about the study participation group, collection and analysis of data.

\section{Research Design}

In the research, the phenomenon pattern, which is one of the qualitative research methods, was used to provide an in-depth and detailed knowledge of how the concept of space perception is perceived. The design of phenomena focuses on phenomena that we are aware of but do not have an in-depth and detailed understanding of. Phenomena can appear in various forms such as events, experiences, perceptions, orientations, concepts and situations in the world we live in (Yıldırım and Şimşek, 2008). Teacher candidates ' perception and experiences related to the concept of direction were tried to be revealed.

\section{Working Group}

The working group of this study consists of a total of 261 teachers who studied in the Departments of Turkish, Social Sciences and Primary Education at the Faculty of Education of Bayburt University in the spring semester of the 2018-2019 academic year. The inclusion of teacher candidates in the study group is due to the inclusion of spatial perception skills in the course programs that these teacher candidates will teach when they are appointed. The number of working groups was considered to be appropriate for the validity and security of the data. Data for the workgroup is given in Table 1. 
Table 1

Working Group

\begin{tabular}{lccccl}
\hline Gender & $\begin{array}{c}\text { Classroom } \\
\text { Teacher }\end{array}$ & $\begin{array}{c}\text { Social Sciences } \\
\text { Teacher }\end{array}$ & $\begin{array}{c}\text { Turkish } \\
\text { Teacher }\end{array}$ & $(\boldsymbol{f})$ & $(\boldsymbol{\%})$ \\
\hline Female & 75 & 45 & 69 & 189 & 72,41 \\
Male & 29 & 21 & 22 & 72 & 27,59 \\
\hline Total & $\mathbf{1 0 4}$ & $\mathbf{6 6}$ & $\mathbf{9 1}$ & $\mathbf{2 6 1}$ & $\mathbf{1 0 0}$ \\
\hline
\end{tabular}

When Table 1 examined, the majority of the teacher candidates in the study consisted of $\mathrm{N}=189(72.41 \%)$ female students, while the number of male teacher candidates in the group was $n=72(27.59 \%)$.

\section{Data Collection}

The relevant literature (Geçit and Gençer, 2011; Kelleci, 2014; Özkan and Taşkın, 2014; Beyoğlu and Ergin, 2018; Duran and Aladağ (2018); Değirmenci and Eskici, 2019) was examined while developing the data collection tool. Of the teacher candidates who participated in the study in order to determine their thoughts towards the concept of spatial perception, "the perception of spatial... e / a is like / because..."the semi-structured forms that are written are given. The teacher candidates were asked to write together their own metaphor for the concept of space perception on the grounds. In works where metaphors are used " like / similar... ". the word " is generally used to better explain the link between the subject of the mental image and the source of the mental image. "Because... the word" is used to provide a logical basis for the metaphors produced (Saban, 2008). Teacher candidates are given a 15-minute period to write the form. What is written in these forms formed the main data source of the study.

\section{Data Analysis}

The data obtained in the research were analyzed using content analysis. The main purpose of content analysis is to reach concepts and relationships that explain the collected data. The aim of this course is to bring together similar data within the framework of specific concepts and themes in content analysis and to organize and interpret them in a way that the reader can understand (Yıldırım and Şimşek, 2008).

The content analysis was analyzed by considering the four phases classified by Kilcan (2017). These phases are (1) the encoding and extracting phase of metaphors, (2) the compilation phase of metaphors, (3) the category development phase, (4) the validity and reliability phase, and (5) the transfer of data to computer media.

(1) Metaphor coding and extraction phase: in this phase he examined the participle forms given sequence number starting from one by looking at whether the spatial perception metaphor was clearly expressed. The forms in which the metaphor is written and there is no justification, where the metaphor is defined and the metaphor is not realized are marked and taken out of analysis.

(2) Stage of compiling sample metaphors: at this stage the connection between each metaphor resembling (1), being likened to (2), and being likened to (3) and being 
likened was analyzed. At this stage, the participants looked at whether a common point between the likened and the likened should be taken into account.

(3) Category development phase: in this phase, categories are formed by looking at words that fall within the same concept area of metaphors developed by the participants. Because their closer beings are interpreted as more similar (Fabrikant, Monteilo, Mark, 2006).

(4) The stage of ensuring validity and reliability: all metaphors and categories created in this stage are given to the relevant experts in a list. The reliability of the research was calculated by using the formula for reliability (Consensus/Consensus + difference of opinion) (Miles and Huberman 1994), taking into account the opinions of the experts. The reliability of this study was calculated as $109 / 109+3=0.97$.

(5) Transfer of data to computer media stage: after the 109 metaphors created by the participants for the perception of space were divided into 10 categories, the metaphors were transferred to computer media. The number of participants (f) and percentage (\%) representing the metaphors and the category in which they are found were calculated.

\section{Findings}

The metaphors of the teachers involved in the study regarding the concept of perception of spatial are presented under two main titles. These titles are stated as" metaphors developed by teacher candidates for the concept of perceiving spatial" and categories of metaphors developed by teacher candidates for the concept of perceiving spatial". The metaphors developed by the teacher candidates for the concept of spatial perception are given in Table 2.

Table 2

Teacher Candidates' Thoughts Regarding Concept on Perception of Spatial through Metaphors

\begin{tabular}{cccccccc}
\hline Number & $\begin{array}{c}\text { Created } \\
\text { Metaphor }\end{array}$ & $\begin{array}{c}\text { Frequency } \\
(\mathbf{f})\end{array}$ & $\begin{array}{c}\text { Percent } \\
(\mathbf{\%})\end{array}$ & Number & $\begin{array}{c}\text { Created } \\
\text { Metaphor }\end{array}$ & $\begin{array}{c}\text { Frequency } \\
(\mathbf{f})\end{array}$ & $\begin{array}{c}\text { Percent } \\
(\boldsymbol{\%})\end{array}$ \\
\hline $\mathbf{1}$ & House & 29 & 11,13 & 56 & Son & 1 & 0,38 \\
\hline $\mathbf{2}$ & Place & 19 & 7,29 & 57 & Universe & 1 & 0,38 \\
\hline $\mathbf{3}$ & Viewpoint & 11 & 4,22 & 58 & Planet & 1 & 0,38 \\
\hline $\mathbf{4}$ & Family & 9 & 3,45 & 59 & Observation & 1 & 0,38 \\
\hline $\mathbf{5}$ & Country & 7 & 2,69 & 60 & Glasses & 1 & 0,38 \\
\hline $\mathbf{6}$ & Mirror & 6 & 2,29 & 61 & Sun & 1 & 0,38 \\
\hline $\mathbf{7}$ & İmagine & 6 & 2,29 & 62 & Safe & 1 & 0,38 \\
\hline $\mathbf{8}$ & Human & 6 & 2,29 & 63 & Beauty & 1 & 0,38 \\
\hline $\mathbf{9}$ & Library & 6 & 2,29 & 64 & Camera & 1 & 0,38 \\
\hline $\mathbf{1 0}$ & Homeland & 6 & 2,29 & 65 & Map & 1 & 0,38 \\
\hline $\mathbf{1 1}$ & Duygu & 5 & 1,92 & 66 & Everybody & 1 & 0,38 \\
\hline $\mathbf{1 2}$ & Düşünce & 5 & 1,92 & 67 & Heart & 1 & 0,38 \\
\hline $\mathbf{1 3}$ & School & 5 & 1,92 & 68 & Turtle & 1 & 0,38 \\
\hline $\mathbf{1 4}$ & Sea & 4 & 1,53 & 69 & Character & 1 & 0,38 \\
\hline $\mathbf{1 5}$ & Sky & 4 & 1,53 & 70 & Black Hole & 1 & 0,38 \\
\hline $\mathbf{1 6}$ & Serenity & 4 & 1,53 & 71 & Brother & 1 & 0,38 \\
\hline
\end{tabular}




\begin{tabular}{|c|c|c|c|c|c|c|c|}
\hline 17 & Inspired & 4 & 1,53 & 72 & Ant & 1 & 0,38 \\
\hline 18 & Mother & 3 & 1,15 & 73 & Kayseri & 1 & 0,38 \\
\hline 19 & Blank & 3 & 1,15 & 74 & Myself & 1 & 0,38 \\
\hline 20 & Nature & 3 & 1,15 & 75 & Book & 1 & 0,38 \\
\hline 21 & World & 3 & 1,15 & 76 & Bird's Nest & 1 & 0,38 \\
\hline 22 & See & 3 & 1,15 & 77 & Box & 1 & 0,38 \\
\hline 23 & Breath & 3 & 1,15 & 78 & Light & 1 & 0,38 \\
\hline 24 & Forest & 3 & 1,15 & 79 & Neighborhood & 1 & 0,38 \\
\hline 25 & Environment & 3 & 1,15 & 80 & Judgment & 1 & 0,38 \\
\hline 26 & Water & 3 & 1,15 & 81 & $\begin{array}{l}\text { Machine } \\
\text { System }\end{array}$ & 1 & 0,38 \\
\hline 27 & Tree & 2 & 0,77 & 82 & Message & 1 & 0,38 \\
\hline 28 & Mosque & 2 & 0,77 & 83 & Grave & 1 & 0,38 \\
\hline 29 & Flower & 2 & 0,77 & 84 & Happiness & 1 & 0,38 \\
\hline 30 & $\begin{array}{c}\text { Sensory } \\
\text { Organs }\end{array}$ & 2 & 0,78 & 85 & $\begin{array}{c}\text { Music } \\
\text { Instrument }\end{array}$ & 1 & 0,38 \\
\hline 31 & Rainbow & 2 & 0,78 & 86 & Music & 1 & 0,38 \\
\hline 32 & View & 2 & 0,78 & 87 & Room & 1 & 0,38 \\
\hline 33 & Life & 2 & 0,78 & 88 & Oxygen & 1 & 0,38 \\
\hline 34 & Clam & 2 & 0,78 & 89 & $\begin{array}{c}\text { Bus } \\
\text { Window }\end{array}$ & 1 & 0,38 \\
\hline 35 & Compass & 2 & 0,78 & 90 & Ocean & 1 & 0,38 \\
\hline 36 & Dream & 2 & 0,78 & 91 & Teacher & 1 & 0,38 \\
\hline 37 & Class & 2 & 0,78 & 92 & Bias & 1 & 0,38 \\
\hline 38 & Turkey & 2 & 0,78 & 93 & Window & 1 & 0,38 \\
\hline 39 & Lives & 2 & 0,78 & 94 & Color & 1 & 0,38 \\
\hline 40 & Road & 2 & 0,78 & 95 & Picture & 1 & 0,38 \\
\hline 41 & Mind & 2 & 0,78 & 96 & Roman & 1 & 0,38 \\
\hline 42 & Alert & 1 & 0,38 & 97 & Wind & 1 & 0,38 \\
\hline 43 & Mall & 1 & 0,38 & 98 & Hour & 1 & 0,38 \\
\hline 44 & Anatolia & 1 & 0,38 & 99 & Person & 1 & 0,38 \\
\hline 45 & Garden & 1 & 0,38 & 100 & Wake & 1 & 0,38 \\
\hline 46 & Plant & 1 & 0,38 & 101 & Food & 1 & 0,38 \\
\hline 47 & Chameleon & 1 & 0,38 & 102 & Orphanage & 1 & 0,38 \\
\hline 48 & Bursa & 1 & 0,38 & 103 & Lack & 1 & 0,38 \\
\hline 49 & Geography & 1 & 0,38 & 104 & Journey & 1 & 0,38 \\
\hline 50 & Çukurova & 1 & 0,38 & 105 & Egg & 1 & 0,38 \\
\hline 51 & Mountain & 1 & 0,38 & 106 & Dormitory & 1 & 0,38 \\
\hline 52 & Wave & 1 & 0,38 & 107 & Nesting & 1 & 0,38 \\
\hline 53 & Diyarbakır & 1 & 0,38 & 108 & $\begin{array}{c}\text { Time } \\
\text { Tunnel }\end{array}$ & 1 & 0,38 \\
\hline 54 & Wall & 1 & 0,38 & 109 & Intelligence & 1 & 0,38 \\
\hline 55 & Erzurum & 1 & 0,38 & & & & \\
\hline
\end{tabular}

When table 2 is examined, it is seen that 109 metaphors for the concept of space perception were developed by the teachers who participated in the research. When one examines these metaphors, it is seen that they are generally in a positive perception 
$11.13 \%$ of respondents compared the perception of space to home, $7.29 \%$ compared the perception of space to mood (perspective) and $4.22 \%$ compared the perception of space to home. In addition, the metaphors for which the concept of perception of space is most likened are expressed as family $3.45 \%$, hometown $2.69 \%$, mirror $2.29 \%$, imagination $2.29 \%$, human $2.29 \%$, library $2.29 \%$, Homeland $2.29 \%$, emotion $1.92 \%$, thought $1.92 \%$, school $1.92 \%$, sea $1.53 \%$, peace $1.53 \%$ and inspiration $1.53 \%$ respectively. In Table 3 , the categories of metaphors developed by the teacher candidates are given.

Table 3

Teacher Candidates' Thoughts Regarding Concept on Perception of Spatial through Metaphors Category

\begin{tabular}{|c|c|c|c|c|}
\hline Category & Metaphors & $\begin{array}{l}\text { Metaphor } \\
\text { Numbers }\end{array}$ & $\begin{array}{l}\text { Metaphor } \\
\text { Frequency }\end{array}$ & $\begin{array}{l}\text { Metaphor } \\
\text { Percent }\end{array}$ \\
\hline $\begin{array}{l}\text { Perception of } \\
\text { spatial as a } \\
\text { social spatial }\end{array}$ & $\begin{array}{l}\text { Place(19), Family (9) Home (7), } \\
\text { Human (6), Homeland (6), Mother } \\
\text { (3), Environment (3), Turkey (2), } \\
\text { Road (2) Anatolia (1), Bursa (1), } \\
\text { Michigan (1), Diyarbakır (1), } \\
\text { Erzurum (1), Son (1), Everybody } \\
\text { (1) Brother (1), Kayseri (1) } \\
\text { Myself (1), NeigLSourhood (1), } \\
\text { Teacher (1), Person (1). }\end{array}$ & 22 & 70 & 26,81 \\
\hline $\begin{array}{l}\text { Perception of } \\
\text { spatial as } \\
\text { architectural } \\
\text { spatial }\end{array}$ & $\begin{array}{l}\text { House (29), Library (6), School } \\
\text { (5), Class (2), Mosque (2), } \\
\text { Orphanage (1), Mall (1), Garden } \\
\text { Wall (1), Wall (1), Room (1), } \\
\text { Window (1), Nesting (1), } \\
\text { Homeland (1). }\end{array}$ & 13 & 52 & 19,92 \\
\hline $\begin{array}{l}\text { Perception of } \\
\text { spatial as a } \\
\text { field of } \\
\text { emotion- } \\
\text { thought }\end{array}$ & $\begin{array}{l}\text { Mood (viewpoint) (11), } \\
\text { imagination (6) Emotion (5) } \\
\text { thinking (5), Peace (4) Inspiration } \\
\text { (4), Sight (2) Dream (2), } \\
\text { Observation (1), Beauty (1), Trust } \\
\text { (1), Character (1) Happiness (1), } \\
\text { Bias (1). }\end{array}$ & 14 & 45 & 17,25 \\
\hline $\begin{array}{l}\text { Perception of } \\
\text { spatial as a } \\
\text { natural spatial }\end{array}$ & $\begin{array}{l}\text { The Sky (4) SEA (4), Nature (3), } \\
\text { World (3) Forest (3), Su (3), } \\
\text { Wood (2), Chichewa (2) Rainbow } \\
\text { (2), Plant (1), Mountain (1), Wave } \\
\text { (1), Universe (1), Planet (1) Sun } \\
\text { (1) Ocean (1), Wind (1). }\end{array}$ & 17 & 34 & 13,03 \\
\hline $\begin{array}{l}\text { Perception of } \\
\text { spatial as a } \\
\text { field of tools } \\
\text { and equipment }\end{array}$ & $\begin{array}{l}\text { Mirror (6), Compass (2), alarm (1) } \\
\text { camera (1), Glasses (1) Map (1), } \\
\text { Book (1) Box (1) Lamp (1), } \\
\text { machine systems (1) musical } \\
\text { instruments (1), the bus window } \\
(1), \text { novel (1), Hour (1). }\end{array}$ & 14 & 20 & 7,66 \\
\hline $\begin{array}{l}\text { Perception of } \\
\text { space as body- }\end{array}$ & $\begin{array}{l}\text { See (3), breath (3), sensory organs } \\
\text { (2), Life (2), Life (2), Mind (2), }\end{array}$ & 10 & 18 & 6,89 \\
\hline
\end{tabular}




\begin{tabular}{lllll}
\hline $\begin{array}{l}\text { part function } \\
\text { spatial }\end{array}$ & $\begin{array}{l}\text { Heart (1), oxygen (1), Wake (1), } \\
\text { intelligence (1). }\end{array}$ & & & \\
\hline $\begin{array}{l}\text { Perception of } \\
\text { spatial as a } \\
\text { field of } \\
\text { obscurity }\end{array}$ & $\begin{array}{l}\text { Blank (3), Black Hole (1), } \\
\text { Armageddon (1), Tomb (1), color } \\
\text { (1), absence (1), Time Tunnel (1). }\end{array}$ & 7 & 9 & \\
\hline $\begin{array}{l}\text { Perception of } \\
\text { spatial as an } \\
\text { animal species }\end{array}$ & $\begin{array}{l}\text { Clam (2), Chameleon (1), Turtle } \\
\text { (1), Ant (1), Bird's Nest (1), egg }\end{array}$ & 6 & 7 & 2,69 \\
\hline $\begin{array}{l}\text { Perception of } \\
\text { spatial as a } \\
\text { field of } \\
\text { science }\end{array}$ & $\begin{array}{l}\text { Geography (1), Music (1), Picture } \\
\text { Perception of }\end{array}$ & 3 & 3 & 1,15 \\
$\begin{array}{l}\text { space as other } \\
\text { areas }\end{array}$ & \begin{tabular}{l} 
Food (1), Journey (1), Message \\
\multicolumn{1}{c}{ Total }
\end{tabular} & 3 & 3 & 1,15 \\
\hline
\end{tabular}

When table 3 was examined, the metaphors developed by the teacher candidates were collected in 10 different categories. These categories respectively (1) "the perception of spatial as Social Spatial", (2) "architectural spatial as spatial perception", "emotion-thought of spatial as a field of perception" (4) "natural areas as spatial perception" (5) "the perception of spatial as equipment space", (6) "physical-spatial partition function as a field of perception" (7)"the perception of spatial as an area of obscurity", (8) "the perception of spatial as a type of animal", (9) "Spatial science as a field of perception" (10) "other areas as spatial perception" are the categories. From these categories, 70 teacher candidates in the category" perception of spatial as social spatial" have developed 22 different metaphors. In the" perception of spatial as an architectural space " category, 52 teachers have developed 13 different metaphors. " Perception of spatial as a space of emotion-thought", 45 teacher candidates have developed 14 different metaphors. In the" perception of spatial as a natural spatial" category, 34 teacher candidates have developed 17 different metaphors. In the category" perception of spatial as a field of tools", 20 teacher candidates have developed 14 metaphors. In the category" body-part perception of spatial as a function space", 18 teacher candidates have produced 10 different metaphors. In the category" perception of spatial as an unknown", 9 teacher candidates have developed 7 metaphors. In the category" perception of spatial as an animal species", 7 teacher candidates have developed 6 metaphors. In the category" perception of spatial as a field of science", 3 teacher candidates have developed 3 metaphors. In the category" perception of spatial as other fields", 3 teacher candidates have developed 3 metaphors.

\section{Category 1. Perception of Spatial As a Social Spatial}

Table 3 is examined under this category towards the concept of spatial perception, respectively, in (19), family (9) home (7), human (6), homeland (6), mother (3), medium (3), Turkey (2), path (2) Anatolia (1), Bursa (1), Michigan (1), Diyarbakır (1), Erzurum (1), son (1), everyone (1) sister (1), Kayseri, Turkey (1) myself (1), neighborhood (1) teacher (1), party (1), such as various metaphors, it is seen that 
improved. Examples of metaphorical expressions created by teacher candidates related to this category are given below.

The perception of spatial is like place because wherever I feel happy and peaceful I belong there (S58).

The perception of spatial is similar to the country because it is where you value and care (S120).

The perception of spatial is similar to homeland because you identify with yourself (S115).

The perception of spatial is similar to the medium, because the human brain cannot think of space without the medium (S175).

The perception of spatial is like Turkey, because wherever man goes he is only free in his own country ( $\mathrm{S} 88$ ).

The place is like the road, because you go out to achieve your goal (S114).

The perception of spatial is like family, because in the family we all belong together, we are a whole (S111).

The perception of spatial is like human beings, because each person is different. Each person is different in being affected by a phenomenon and event (S65).

The perception of spatial is like the mother, for she is the most protective and most peaceful Mother (S23).

\section{Category 2. Perception of Spatial As Architectural Space}

Table 3 is examined under this category towards the concept of spatial perception, respectively, house (29), library (6) school (5), class (2) mosque (2), orphanage (1), shopping center (1), wall (1), wall (1), room (1), window (1), socket (1), dormitory (1) it is seen that improved, such as various metaphors. It is pointed out that this category is the category in which most metaphors are developed. Examples of metaphorical expressions created by teacher candidates related to this category are given below.

The perception of spatial is similar to home, because I feel safe and comfortable (S26).

The perception of spatial is similar to the library, because it allows us to grasp the world and life and to reach knowledge (S219).

The perception of spatial is similar to school, because it helps us a lot when we improve ourselves and raise our level of education (S184).

The perception of spatial is similar to class, because it allows different personalities to coexist for a single purpose (S246).

The perception of spatial is similar to the mosque, because I feel peaceful (S46).

\section{Category 3. Perception of Spatial As a Field of Emotion-Thought}

Table 3 is examined under this category towards the concept of spatial perception, mood, respectively (viewpoint) (11), imagination (6) emotion (5) thinking (5), peace (4) inspiration (4), sight (2) dream (2), observation (1), beauty (1), trust (1), character (1) happiness (1), bias (1) it is observed that metaphors such as have developed. Examples of metaphorical expressions created by teacher candidates related to this category are given below.

The perception of spatial is similar to the mood, because the perception of space and space is like the body and soul of man. When a man enters a new space, his mind (soul) perceives that space as abstract (S257). 
The perception of spatial is like imagination, because what we perceive when we look at Space is as much as our imagination (S230).

The perception of spatial is similar to emotion, because everyone feels different emotions when they look at something. Sometimes good feelings and sometimes negative feelings (S25).

The perception of spatial is like thought, because individuals perceive what they see according to their own thoughts (S177).

The perception of spatial is like peace, because when you can't get enough to spend time where you find peace, you want to run away from where you're not at peace (S41).

Perception of spatial is like inspiration, because it makes people think more effectively (S205).

Perception of spatial is like vision, because it is shaped like how you look at it (S127).

The perception of spatial is like a dream, because when you remember it becomes important, it becomes a companion to you. If you do not remember, it disappears like a dream (S169).

\section{Category 4. Perception of Spatial As a Natural Space}

Table 3 is examined under this category towards the concept of spatial perception, respectively skies (4) sea (4), nature (3), world (3) forest (3), su (3), wood (2), chichewa (2) rainbow (2), plant (1), mountain (1), wave (1), universe (1), planet (1) sun (1) ocean (1), wind (1), it is observed that metaphors such as have developed. Examples of metaphorical expressions created by teacher candidates related to this category are given below.

The perception of spatial is like the sky, for it is vast (S222).

The perception of spatial is similar to nature because it gives comfort and peace to man (S55).

The perception of spatial is similar to the world, because it is necessary for our actions in everyday life (S261).

The perception of spatial is similar to the forest, because it is the mother of nature" (S167)

The perception of spatial is like water, because it has one visible and one invisible aspect (S49).

The perception of spatial is like a tree, because it clings to life by putting roots in a place (S159).

The perception of spatial is similar to flower, because a flower has to adapt to an environment in order to know magic (S245).

The perception of spatial is like a rainbow, because it has different colors that are remarkable for everyone (S67).

\section{Category 5. Perception of Spatial As a Field Of Tools and Equipment}

When table 3 is examined, the concept of spatial perception under this category towards, respectively, mirror (6), compass (2), alarm (1) camera (1), glasses (1) map (1), book (1) box (1) lamp (1), mechanical systems (1) musical instruments (1), the bus window (1), fiction (1), h (1), it is observed that metaphors such as have developed. Examples of metaphorical expressions created by teacher candidates related to this category are given below.

The perception of spatial is like a mirror, because it reflects what always (S238) is.

The perception of spatial is like a compass, because it prevents us from getting lost by guiding us to our destination (S236). 
The perception of spatial is like spectacle, because it makes our mind clear (S157).

The perception of spatial is like clockwork, because it constantly works and changes (S14).

\section{Category 6. Perception of Spatial As Body-Part Function Space}

Table 3 is examined under this category towards the concept of spatial perception, respectively (see 3), breathable (3), sense organs (2), life (2) life (2), mind (2) heart (1) oxygen (1), wake (1), intelligence (1) it is observed that metaphors such as have developed. Examples of metaphorical expressions created by teacher candidates related to this category are given below.

Perception of spatial is like seeing, because seeing is being aware of something (S228).

The perception of spatial is like breathing, because man cannot live when he is not breathing (S227).

The perception of spatial is like the sensory organs, because each sensory organ perceives and reacts in a different way (S34).

The perception of spatial is like life, because life makes the person alive, and the perception of space makes the place alive (S77).

The perception of spatial is like life, because as you live you learn new things (S182).

The perception of spatial is like the mind, because it is the center of perceiving and interpreting life (S251).

\section{Category 7. Perception of Spatial As a Field of Obscurity}

Table 3 is examined under this category towards the concept of spatial perception, respectively metaphors such as space (3), black hole (1), Armageddon (1), tomb (1), color (1), absence (1), time tunnel (1) for the concept of space perception. Examples of metaphorical expressions created by teacher candidates related to this category are given below.

The perception of spatial is like emptiness, without our perceptions the gaps do not fill (S156).

The perception of spatial is like Armageddon, it brings all beings together (Ö163).

The perception of spatial is like a tomb, without the perception of space everything disappears (S183).

The perception of spatial is similar to color, it takes on different colors according to the place (S15).

\section{Category 8. Perception of Spatial As an Animal Species}

Table 3 is examined under this category towards the concept of spatial perception, respectively they appear to have developed metaphors such as calm (2), chameleon (1), turtle (1), ant (1), bird's nest (1), egg (1). Examples of metaphorical expressions created by teacher candidates related to this category are given below.

The perception of spatial is like oysters, living safely among oyster shells (S50).

The perception of spatial is like Chameleon, people take on the color of the space they are in (S142).

The perception of spatial is like a turtle, the turtle protects itself by retreating into its shell.

We are protected according to the perception of space" (S53). 


\section{Category 9. Perception of Spatial As a Field of Science}

When table 3 is examined, it is seen that they developed metaphors such as geography (1), music (1), and picture (1) for the concept of space perception under this category. Examples of metaphorical expressions created by teacher candidates related to this category are given below.

The perception of spatial is like geography, it examines the nature and human activities we are in (S242).

The perception of spatial is like music, it's universal for everyone (S57).

The perception of spatial is like painting, reflecting emotions and thoughts with colors (S243).

\section{Category 10. Perception of spatial as other areas:}

When table 3 is examined, it is seen that they developed metaphors for the concept of space perception under this category, such as message (1), food (1) and journey (1) respectively. Examples of metaphorical expressions created by teacher candidates related to this category are given below.

The perception of spatial is like a message, it informs its existence (S44).

The perception of spatial is like food, it is necessary for human survival (S99).

Perception of spatial is like travel, they are constantly travelling between places (S86).

\section{Result and Conclusion}

In this study, Turkish, Social Sciences and Primary Education Departments of teacher candidates for the concept of perception of spatial with the help of metaphors were tried to be put forward. As a result of the research, 109 metaphors were collected in 10 categories. Of these categories, the perception of spatial as social, architectural and natural space categories were determined that 156 of the 261 teacher candidates, i.e. $59.04 \%$, associate the perception of spatial image in their minds with words such as "Place, Place, home, dormitory, sky, space (Turkish Language Institution [TDK], 2011), an empty environment, Infinity, the place where the facts are classified and the place of social relation (Lefebvre, 2016) Beyoğlu and Ergin (2018)'s "metaphorical perceptions of the concept of space of students in the Department of Fine Arts Education" study shows that the most produced "home, school and world" coincides with metaphor. Saban (2008) the most produced metaphor in his work "metaphors for school" appears to be "home". This situation illustrates the ontological interaction of spatial perception.

When the metaphors produced by the teacher candidates for the concept of spatial perception are examined under categories, it is seen that the most commonly produced metaphor is in the category "spatial perception as a social spatial". After this category, teacher candidates developed metaphors that were most commonly included in the category" perception of spatial as an architectural spatial" and later in the categories "perception of space as a space of emotion and thought". The area where the least metaphor is produced appears to be in the category" perception of spatial as a field of science". It was determined that the categories "spatial as a physical structure" and "spatial as a feeling", which produced the most metaphors in the work of Beyoğlu and Ergin (2018), did not overlap. The reason for this is that place is more of a concrete 
symbol, whereas the perception of space is assumed to be due to the teacher candidates seeing ontologically a symbol of mutual interaction.

These areas of metaphor include the sheltering of the outer shell of architectural spaces, trust, peace, comfort, happiness, academic development, keeping differences together, understanding life and the world, etc. it has been determined that they match metaphorically with their justification. In this context, Bonde (2005) coincides with the conclusion that castles and houses are a metaphor for the need for people to feel more confident, keeping, caring and protecting themselves. Lagopoulos (2009) and Caballero (2014) view that architectural spaces have a mutual interaction with people, that architectural spatial are shaped according to people's feelings and thoughts during construction, and that architectural spaces influence people's feelings and thoughts, and the results of the study support each other.

It can be said that they shape the perception of spatial according to social culture. Social spatial themselves are seen to match metaphors in which they are born and raised, happy and peaceful, identify with themselves, are free, and feelings of belonging come to the fore. Erbay (2013) the feeling of human spatial is embraced with a commitment, with the Husn-i acceptance of sincerity and loyalty due to belonging, and it supports the idea that it expresses its commitment to its neigLSorhood, country and homeland within the framework of belonging and affiliation within the framework of beliefs and values. In this context, Kafka's view of Prague, Austria and the Palestinian territories as real spatial (Sar1, 2009) is a reflection of social culture. It is seen that they communicate their social space metaphors one-to-one in their own lives and metaphorically associate them with role-model persons. It is concluded that they are given metaphorically with an understanding that has an important place in their own lives and also emphasizes individual differences.

The perception of space as a natural spatial appears to match metaphorically with the beings in the natural environment present in their environment. This situation was determined primarily to match the perception of spatial with concrete objects. It is seen that this area gives people peace, that it is necessary for daily life and that it is the source of life and that it holds all the differences together.

Lagopoulos (2009) the idea that the cosmogony and cosmology of pre-capitalist societies form the core of the worldview and that this organization is based on the metaphor of spatial supports this metaphorical category. In addition, Bonde (2005) the idea that man identifies with himself and physical spaces and that the forest and the lake represent his own body supports the perception of spatial ontologically.

Body parts functionally, people have an important place in the life of a quality of these organs are given by analogy. It is seen that these organs give by associating positive functions that they add to their own lives. Giesecke (2014) in his study the concept of library bears similarity to the conclusion that it is characterized as the heart of the university. Ahn and Kwon (2007) use words of functional importance more often metaphorically, and Gibbs, Lima and Francozo (2004) can be said to coincide with the fact that the poet Neruda presented his desired body parts in his poetry using detailed metaphorical definitions. 
They seem to match metaphorically according to their own experience in the field of emotion and thought. It has been determined that they relate the perception of spatial to the reasons that spaces allow people to think differently, dream differently, experience different emotions and grow up in different ways. This situation can be summarized in Erbay (2013)'s "one of the best examples of how human perception of spatial changes according to human mood can be summarized in the views of Pushkin, Tournefort and Tanpinar to Erzurum. Tournefort sees Erzurum as the "paradise of the world", while Pushkin makes more vibrant because of his hatred of the "owner of the homeland". Tanpınar also perceived values like a lover who got his love is evidenced by the expressions. In addition, space can cause depression, anxiety and emotional vulnerability. The idea that people conceptualize this situation with negative words supports metaphors related to the concept of spatial perception.

It is seen that the teacher candidates again identify the field of obscurity with their own experiences. Life is sometimes full of surprises. Not what you want to see, but what you see will shape the perception of space again. As a field of science, it was determined that teachers metaphorically matched the concept of space perception according to their academic level. It is seen that geography is a science of space, that people express their feelings, perceptions, with music and painting, and that they match themselves with the reasons that they can develop themselves with books. The metaphorical concepts used as animal elements are primarily given to animals that provide their own shelter with their own shells. It has been determined that the perception of space covers reasons such as "safe, color of space, orientation, sound". These animals carry their own space, direction finding features, according to the environment they are perceived as a positive approach because they come to the fore with the characteristics that shape their perception. Bonde (2005) shows the snail as a symbol of rest and comfort, and Dos Santos, Gros, Abel, Loisel, Trichaud and Paris (2000) shows the bird as a symbol of freedom.

According to Maslow's hierarchy of needs, there is a similarity between the needs in the physiological needs step and the metaphors in the area of architectural, social, physical and vital importance. This step of Maslow's hierarchy of needs covers the essential needs to sustain one's life. Metaphorically associating the perception of space with these concepts is important in terms of showing how vital it is. It should also be noted that social space metaphors are included in Maslow's step of social needs.

- The results of this study are consistent with home (12.14\%) and school (4.62\%) results among the most generated metaphors in the study of Beyoğlu and Ergin (2018). Considering that geography is a science of space and place, Geçit and Gençer's (2010) 'classroom teaching 1. In the study of determining the perceptions of geography by means of metaphor (Rize University example), it is observed that the concept of geography most metaphorically matches the concepts of life (11\%), Sun (5\%), Universe (4\%) and Human (3\%). The concept of Homeland most family $(20,12 \%)$, home $(6.71 \%)$ metaphors in " primary school metaphors" studies of Özkan and Taşkın (2014); school concept most home $(22,6 \%)$, home $(8,6 \%)$, family $(5,6 \%)$, mother $(2,4 \%)$ metaphors in Saban 
(2008)'s "school metaphors" study; Duran and Aladağ (2018) 's "secondary school students "perceptions of Homeland concept determined by metaphor" survey there were metaphors "main (14.3\%), family (8\%), household $(5.2 \%)$ that were very formed. Again in a different study (Değirmenci, 2019b), participants note that they associate the concept of homeland with metaphors such as mother (15.8\%), family (11.53\%), home (7.69\%) and world (5.76\%). It can be said that the students ' perceptions of space match with the concepts that they consider a value to them and coincide with the results of this study. The findings and recommendations developed based on the results of the research are as follows.

- Metaphors can be used as a teaching method to reveal learning for upper cognition in students.

- Metaphors can positively influence students ' academic development by connecting with real life.

- Teaching the concept of spatial perception with metaphors can lead students to think original and increase their creativity about the concept.

\section{References}

Ahn, J. H. \& Kwon, J. Y. (2007). A study of metaphor and metonomy of hand. Journal of Language Science, 14, 195-215.

Akbaş, Y. \& Gençtürk, E. (2013). Metaphorical perspective to geographical information system concepts. Dicle University Journal of Ziya Gokalp Education Faculty, 21, 179-196.

Aydın, F. (2011). The metaphoric perceptions of university students towards "environment" concept. Eastern Geographical Review, 16(26), 25-44.

Aydin, İ. S. \& Pehlivan, A. (2010). The metaphors that Turkish teacher candidates use concerning "teacher" and "student" concepts. Turkish Studies, 5(3), 818-842.

Bektaş, M. \& Karadağ, B. (2013). The analysis of metaphors that primary school 4. grade students developed for cooperating value. Turkish Studies-International Periodical for the Languages, Literature and History of Turkish or Turkic, 8(8), 271-286.

Bektaş, M., Okur, A. \& Karadağ, B. (2014). Book as a metaphoric perception in last class of'the primary and secondary students. Türk Kütüphaneciliği, 28(2), 154-168.

Beyoğlu, A. \& Ergin, D. Y. (2018). Metaphorical perceptions of students in fine arts education departments on the concept of location. HUMANITAS-Uluslararast Sosyal Bilimler Dergisi, 6(11), 71-90.

Bonde, L. O. (2005). "Finding a new place" Metaphor and narrative in one cancer survivor's BMGIM therapy. Nordic Journal of Music Therapy, 14(2), 137-154.

Bulut, A. \& Dursun, F. (2019). The active learning model of class 7 students and their impacts on critical thinking tendencies teacher opinions. Journal of History School (JOHS), 12 (XL), 12-31.

Burmakova, E. A. \& Marugina, N. I. (2014). Cognitive approach to metaphor translation in literary discourse. Procedia-Social and Behavioral Sciences, 154, 527-533. 
Caballero, R. (2014). Language, space and body: Sensing and construing built space through metaphor. Space, place and the discursive construction of identity, 107-134.

Çağbayır, Y. (2009). Edib Ahmed Bin Mahmud Yüknekî günümüz diliyle Atebetü'l-Hakâyık gerçeklerin eşiği. İstanbul: Ötüken Neşriyat.

Cerit, Y. (2010). Students, teachers and administrators' views on metaphors with respect to the concept of principal. Ë̆itim ve Bilim, 33(147), 3-13.

Değirmenci, Y. \& Eskici, B. (2019). Examination of prospective teachers' perceptions of active citizenship. OPUS Uluslararası Toplum Araştırmaları Dergisi, 11(18), 233-256.

Değirmenci, Y. (2019a). An examination of metaphors regarding the concept of "natural disaster" developed by prospective classroom teachers. International Journal of Geography and Geography Education, 39, 83-94.

Değirmenci, Y. (2019b). Examination of prospective teachers' perceptions of homeland: A phenomenological study. Review of International Geographical Education Online (RIGEO), 9(2), 346-360.

Dos Santos, C. R., Gros, P., Abel, P., Loisel, D., Trichaud, N. \& Paris, J. P. (2000, October). Metaphor-aware 3d navigation. In IEEE Symposium on Information Visualization 2000. INFOVIS 2000. Proceedings (pp. 155-165). IEEE.

Duran, Y. \& Aladağ, C. (2018). Determining secondary school students' perceptions about the concept of homeland with metaphor. Electronic Turkish Studies, 13(19). 589-614

Durmuş, E. \& Baş, K. (2016). The metaphoric perception of social sciences teacher candidates about the concept of geography. Firat University Journal of Social Sciences/Sosyal Bilimler Dergisi, 26(1).

Edilmen-Ocak, Ş. E., Çiydem, E. \& Mindivanl1-Akdoğan, E. (2017). Perspectives on social studies teacher candidates' metaphor perceptions for culture and identity concept. $E$ Kafkas Eğitim Araştırmaları Dergisi, 4(3), 59-71.

Erbay, E. (2013). Tanpınar ve Puşkin'de mekân algısı. M. Erkan, İ. Öğretir, A. Utku , ve S. Toska (eds.), In M. Ruhi Esengün'ü Anma Toplantısı (p. 95-122). Erzurum: Atatürk Üniversitesi yayınları.

Erdi-Es, B. (2018). Mirror as a metaphor. İdil Sanat ve Dil Dergisi, 7(52), 1473-1479.

Ertürk, S. (1997). Eğitimde Program Geliştirme. Ankara: Meteksan.

Fabrikant, S. I., Monteilo, D. R. \& Mark, D. M. (2006). The distance-similarity metaphor in region-display spatializations. IEEE Computer Graphics and Applications, 26(4), 34-44.

Geçit, Y. \& Gençer, G. (2011). Determining the geographical perception of the 1st. grade students in the department of primary education through metaphor (Example of Rize University). Marmara Coğrafya Dergisi, (23), 1-19.

Gibbs Jr, R. W., Lima, P. L. C. \& Francozo, E. (2004). Metaphor is grounded in embodied experience. Journal of pragmatics, 36(7), 1189-1210.

Giesecke, J. (2014). Finding the right metaphor: Restructuring, realigning, and repackaging today's research libraries. (Ed. Sul H. Lee) In Repackaging Libraries for Survival (pp. 6071). Routledge. 
Güneş, C. \& Tezcan, R. (2017). Metafor nedir, ne değildir? Kılcan, B. (Ed)., In Metafor ve eğitimde metaforik çalışmalar için bir rehber, (p.1-14). Ankara: Pegem Akademi.

Hopkins, J. (2002). Psychoanalysis, metaphor and the concept of mind. In Analytic Freud (pp. 23-47). Routledge.

Karacabey, M. F. \& Bozkuş, K. (2016). Teacher candidates' metaphors of faculty culture. SOBIDER/Sosyal Bilimler Dergisi, 3(9), 397-410.

Karapınar-Çağlar, B. \& Arıbaş, K. (2017). The metaphorical perceptions of social studies preservice teachers about nature education. Journal of Anatolian Cultural Research, 1(2), 40-66.

Kavcar, C. (2002). Training branch teachers during the republic. Ankara Üniversitesi Eğitim Bilimleri Fakülte Dergisi, 35(1-2), 1-14.

Kelleci, D. (2014). An examination into perceptions of preservice classroom teachers in relation to notion of climate via metaphor. (Yayınlanmamış doktora tezi). Giresun: Giresun Üniversitesi Sosyal Bilimler Enstitüsü.

Kılcan, B. (2017). Eğitim bilimlerinde metaforların veri toplama aracı olarak kullanılması, örnek bir uygulama. Kılcan, B. (Ed)., In Metafor ve eğitimde metaforik çalışmalar için bir rehber, (p.93-112). Ankara: Pegem Akademi

Kitchin, R. M. (1994). Cognitive maps: What are they and why study them? Journal of environmental psychology, 14(1), 1-19.

Köktürk, E. (2010). On the perception of space and the relation of space. Geodesy symposium in spatial planning. İzmir, 24-26 November. Retrieved from http://www.erolkokturk.net/FileUpload/ks85423.

Lagopoulos, A. P. (2009). The social semiotics of space: Metaphor, ideology, and political economy. Semiotica, 2009 (173), 169-213.

Lakoff, G. \& Johnson, M. (2015). Metaforlar hayat, anlam ve dil (Çev. Gökhan Yavuz Demir). İstanbul: İthaki.

Lefebvre, H. (2014). Mekânın üretimi (Çev: Işık Ergüden) 4. Baskı, İstanbul: Sel Yayıncılık.

MEB. (2018a). Hayat bilgisi öğretim programı (İlkokul 1, 2 ve 3. Sınıf). Retrieved from http://mufredat.meb.gov.tr/Dosyalar/2018122171428547-

HAYAT\%20B\%C4\%B0LG\%C4\%B0S\%C4\%B0\%C3\%96\%C4\%9ERET\%C4\%B0M\%2 OPROGRAMI.pdf

MEB. (2018b). Sosyal bilgiler dersi öğretim programı (Illkokul ve Ortaokul 4,5,6 ve 7. sınıflar). Retrieved from http://mufredat.meb.gov.tr/Dosyalar/201812103847686-SOSYAL\% 20B\%C4\%B0LG\%C4\%B0LER\%20\%C3\%96\%C4\%9ERET\%C4\%B0M\%20PROGRAM I\%20.pdf

MEB. (2019). Türkçe öğretim programı (İlkokul ve Ortaokul 1, 2, 3, 4, 5, 6, 7 ve 8. sınıf). Retrieved from http://mufredat.meb.gov.tr/Dosyalar/20195716392253-02-T\%C3\% BCrk\%C3\%A7e\%20\%C3\%96\%C4\%9Fretim\%20Program\%C4\%B1\%202019.pdf

Miles, M. B. \& Huberman, A. M. (1994). An expanded source book qualitative data analysis. (Second edition). Thousand Oaks, California: Sage Publications. 
Nelson, L. D. \& Simmons, J. P. (2009). On southbound ease and northbound fees: Literal consequences of the metaphoric link between vertical position and cardinal direction. Journal of Marketing Research, 46(6), 715-724.

Özkan, R. \& Taşkın, M. A. (2014). The determination of primary school students' perception towards the concept of homeland. Tarih Okulu Dergisi, 7 (XVII), 889-906.

Radden, G. (2003). The metaphor tıme as space across languages. Zeitschrift für interkulturellen Fremdsprachenunterricht, $8(2)$.

Saban, A. (2008). Metaphors about school. Educational Administration: Theory and Practice, 55, 459-496.

Şahin, V. (2017). Space perception in Dede Korkut's stories. Siirt Üniversitesi, Sosyal Bilimler Enstitüsü Dergisi, 8, 1-49.

Salan, Z. \& Gürani, F. Y. (2019). Deity metaphor of light in sacred space. Çukurova Üniversitesi Sosyal Bilimler Enstitüsü Dergisi, 28(2), 18-30.

Sarı, Ahmet (2009). Kafkaesk Anorexia, Franz Kafka'da açlık bilinci ve kültürü, Erzurum: Salkımsöğ̈̈t Yayınları.

Slepian, M. L. \& Ambady, N. (2014). Simulating sensorimotor metaphors: Novel metaphors influence sensory judgments. Cognition, 130(3), 309-314.

Steen, G. J. (2010). Researching and applying metaphor. Toegepaste Taalwetenschap in Artikelen, 83(1), 91-102.

TDK (2011). Türkçe Sözlük, Ankara: Türk Dil Kurumu Yayınları.

Turner, J. (1993). Falling into place: conceptual metaphor and western academic culture. Intercultural Communication Studies, III, 1, 49-61.

Yazıc1, Ö. \& Ulu-Kalın, Ö. (2018). "A comparative analysis of conceptual metaphors for "natural disaster". E-Kafkas Ë̆itim Araştırmaları Dergisi, 5(1), 25-40.

Yıldırım, A. \& Şimşek, H. (2008). Sosyal bilimlerde nitel araştırma yöntemleri (7. Baskı). Ankara: Seçkin yayıncılık.

\section{Biographical Statement}

Dr. Memet KUZEY works as an assistant professor at the Faculty of Education, Bayburt University. His work focus on social sciences education, such as curriculum, methodologies, textbooks, maps, directions and disaster education. 